\title{
PEMETAAN KELOMPOK SEBARAN TITIK GEMPA BUMI MENTAWAI DENGAN METODE K-MEDOIDS CLUSTERING
}

\author{
Yudi Setiawan $^{1)}$, Safroni Aziz Suprianto ${ }^{2)}$, Andangan Wijanarko ${ }^{3)}$, Dyah Setyo Rini ${ }^{4)}$, Mochammad \\ Yusa ${ }^{5)}$ \\ 1,2,3,5 Program Studi Informatika, Fakultas Teknik, Universitas Bengkulu \\ ${ }^{4}$ Jurusan Matematika, Fakultas MIPA, Universitas Bengkulu \\ Email: 1, ${ }^{*} y s e t i a w a n @ u n i b . a c . i d,{ }^{2}$ safroniaziz@email.com, ${ }^{3}$ andang@unib.ac.id, ${ }^{4}$ dyah.setyorini@unib.ac.id, \\ 5mochammad.yusa@unib.ac.id
}

\begin{abstract}
The Indonesian archipelago is on the path of the earth's plate, such as the sharpening of the Indo-Australian Ocean Plate with the Eurasian Continental Plate that extends from the west coast of Sumatra to the southern coast of Java continues to the east to Nusa Tenggara. In Indonesia, the area that is very prone to earthquakes from the seabed is the Mentawai Islands in West Sumatra. The United States Geological Survey (USGS) is a U.S. government scientific agency that has four major scientific disciplines: biology, geography, geology, and water. One of the USGS programs is to monitor earthquake activity around the world, not least the mentawai island earthquake data provided in the form of datasheets. With the advancement of technology, a system is needed that can provide information about mapping the distribution group of earthquake points by clustering earthquakes. This research aims to Build an Information System that can map the pattern of the distribution of earthquakes in 2010 - 2019 and also aims to implement the K-Medoid Clustering method to analyze and map the pattern of the distribution of earthquakes in 2010 - 2019. The resulting external layout of the calculation map from the K-Medoids Clustering method for ten (10) years, namely in 2010 - 2019, there were 1356 data. In addition, there is also a resulting exterior in the form of a bar diagram and a circle diagram.
\end{abstract}

Keyword: Earthquake, Mentawai, K-Medoid Clustering, Geographic Information System, Mapping.

Abstrak

Kepulauan Indonesia berada pada jalur penumjaman lempeng bumi, seperti penunjaman Lempeng Samudra IndoAustralia dengan Lempeng Benua Eurasia yang memanjang dari pantai barat Sumatera hingga pantai selatan Jawa terus ke timur sampai Nusa Tenggara. Di Indonesia, Daerah yang sangat rawan terjadinya gempa bumi dari dasar laut adalah Kepulauan Mentawai di Sumatera Barat. United States Geological Survey (USGS) adalah sebuah agensi ilmiah pemerintah Amerika Serikat yang memiliki empat disiplin ilmiah utama, yaitu biologi, geografi, geologi, dan air. Salah satu program USGS adalah memonitor aktivitas gempa bumi di seluruh dunia, tak terkecuali data gempa kepulauan mentawai yang disediakan dalam bentuk datasheet. Dengan adanya kemajuan teknologi, dibutuhkan suatu sistem yang dapat memberikan informasi mengenai pemetaan kelompok sebaran titik gempa bumi mentawai dengan clustering gempa bumi. Penelitian ini bertujuan untuk Membangun Sistem Informasi yang dapat melakukan pemetaan pola sebaran gempa bumi mentawai tahun 2010 - 2019 dan juga bertujuan untuk mengimplementasikan metode K-Medoid Clustering untuk menganalisis dan memetakan pola Sebaran gempa bumi mentawai tahun 2010 - 2019. Luaran yang dihasilkan berupa layout peta hasil perhitungan dari metode K-Medoids Clustering selama sepuluh (10) tahun yaitu tahun 2010 - 2019 yang terdapat sebanyak 1356 data. Selain itu terdapat juga luaran yang dihasilkan berupa tampilan diagram batang dan diagram lingkaran..

Kata Kunci: Gempa bumi, Mentawai, K-Medoid clustering, Sistem Informasi Geografis, Pemetaan.

\section{Pendahuluan}

Secara geologis Kepulauan Indonesia berada pada jalur penumjaman lempeng bumi, seperti penunjaman Lempeng Samudra Indo-Australia dengan Lempeng Benua Eurasia yang memanjang dari pantai barat Sumatera hingga pantai selatan Jawa terus ke timur sampai Nusa Tenggara. Jalur penunjaman lempeng bumi di wilayah Kepulauan Indonesia merupakan jalur penyebab gempa tektonik yang mana bersifat regional dan umumnya kerusakan yang ditimbulkan sangat parah. Sebagian jalur gempa bumi tersebut berada di laut sehingga sangat berpotensi menimbulkan bencana tsunami [1].

Di Indonesia sendiri, Daerah yang sangat rawan terjadinya gempa bumi dari dasar laut adalah Kepulauan Mentawai 
di Sumatera Barat. Pada tahun 2010 Mentawai mengalami sejumlah gempa, yaitu gempa berkekuatan 6,8 SR pada 5 Maret 2010, disusul 6.5 SR pada 5 Mei 2010 dan terakhir gempa berkekuatan 7,8 SR pada 25 oktober 2010 yang diikuti dengan bencana tsunami [2]. Berdasarkan data dan informasi dari posko BNPB bencana gempa bumi dan tsunami pada 25 oktober 2010 mengakibatkan korban jiwa sebanyak 509 meninggal dunia, 17 orang mengalami lukaluka, dan masyarakat mengungsi sebanyak 11.425 yang tersebar di titik pengungsian di kecamatan Sipora Selatan, Pagai Selatan, Pagai Utara dan Sikakap [3].

United States Geological Survey (USGS) adalah sebuah agensi ilmiah pemerintah Amerika Serikat yang didirikan pada 3 Maret 1879. Organisasi ini memiliki empat disiplin ilmiah utama, yaitu biologi, geografi, geologi, dan air. Salah satu program dari USGS adalah memonitor aktivitas gempa bumi di seluruh dunia, tak terkecuali data gempa kepulauan mentawai yang disediakan dalam bentuk Datasheet.

Pengelompokkan wilayah terjadinya gempa bumi di kepulauan Mentawai, peneliti menggunakan metode $\mathrm{K}$ Medoids Clustering. Metode K-Medoids Clustering diciptakan untuk mengatasi kelemahan algoritma KMeans yang sensitif terhadap outlier, karena nilai yang sangat besar dapat secara substansial mendistorsi distribusi data. Untuk mengatasi hal tersebut algoritma KMedoids tidak mengambil nilai rata - rata dari objek dalam sebuah cluster sebagai titik acuan melainkan menggunakan objek yang sebenarnya untuk mewakili cluster, menggunakan satu objek perwakilan per cluster. Setiap objek yang tersisa berkumpul dengan objek perwakilan yang paling mirip dengan dirinya. Lalu metode partisi dilakukan berdasarkan prinsip meminimalkan jumlah ketidaksamaan antara tiap objek dengan titik referensinya [4].

Penelitian terkait dilakukan sebelumnya oleh [5] yang melakukan penelitian tentang pengelompokkan kejadian gempa bumi dengan menggunakan metode Fuzzy CMeans Clustering. Hasil pengelompokan ditampilkan dalam bentuk tabel dan dalam bentuk koordinat peta Google Maps. Untuk penelitian terkait selanjutnya dilakukan oleh [6] yang melakukan penelitian mengenai Clustering data kejadian tsunami yang disebabkan oleh gempa bumi dengan menggunakan algoritma K-Medoids. Subjek yang terdapat pada penelitian ini adalah aplikasi pengelompokan data dengan menggunakan K-Medoids untuk mengelompokan data kejadian tsunami yang disebabkan oleh gempa bumi. Lalu terdapat penelitin [7] yang berjudul Budaya Kerentanan dan Kapasitas Masyarakat Kepulauan Mentawai Menghadapi Bencana Gempa Bumi dan Tsunami, dari penelitian tersebut didapatkan simpulan yaitu Kabupaten Kepulauan Mentawai merupakan daerah yang memiliki risiko terjadinya gempa bumi besar yang mengakibatkan terjadinya tsunami. Desa Maileppet dan Desa Tuapeijat merupakan daerah yang memiliki risiko untuk terjadi bencana tersebut. Bahaya yang bisa terjadi sewaktu-waktu membuat masyarakat harus waspada dan bersiap menghadapi ancaman tersebut. Yang terakhir terdapat penelitian dari [8] yang berjudul Korelasi Tingkat
Seismisitas dan Periode Ulang Gempa Bumi di Kepulauan Mentawai dengan Menggunakan Metode Guttenberg Richter yang dapat disimpulkan bahwa : Nilai parameter aktivitas gempa bumi untuk daerah penelitian diperoleh nilai b sebesar 0,8372 dan nilai a sebesar 6,8094 serta nilai indeks seismisitas untuk magnitudo $5-8$ berkisar antara 2,1580 - 0,0066, Kondisi ini menunjukkan bahwa daerah Kepulauan Mentawai dan sekitarnya diprediksi memiliki tingkat keaktivan gempa yang tinggi dan memiliki energi besar yang masih tersimpan sehingga berpeluang terjadi gempa besar di wilayah tersebut. Hasil perhitungan periode ulang gempa bumi berbeda-beda untuk magnitudo 5-8 berkisar antara 0,4633 tahun - 150,5033 tahun.

Penelitian yang diusulkan berupa Pemetaan Pola Sebaran Titik Gempa Bumi Mentawai Berdasarkan Kedalaman dan Kekuatan Gempa Dengan Mengimplementasikan metode K-Medoids Clustering dengan studi kasus Gempa di gempa bumi Mentawai 2010-2019 dengan menggunakan datasheet usgs.gov sebagai alternatifalternatif penentuan gempa bumi berdasarkan kedalam dan kekuatan gempa. Adapun tujuan dari dilakukannya penelitian ini adalah untuk mengimplementasikan metode K-Medoid Clustering untuk menganalisis dan memetakan pola Sebaran gempa bumi mentawai tahun 2010 - 2019 . Untuk memetakan pola sebaran gempa bumi tersebut digunakan dua (2) parameter yaitu kedalaman dan kekuatan gempa bumi dengan menggunakan metode $\mathrm{K}$ Medoid Clustering. Luaran yang dihasilkan berupa layout peta hasil perhitungan dari metode K-Medoids Clustering selama sepuluh (10) tahun yaitu tahun 2010 - 2019 yang terdapat sebanyak 1356 data. Selain itu terdapat juga luaran yang dihasilkan berupa tampilan diagram batang dan diagram lingkaran.

\section{Metodologi Penelitian}

Pergerakan Lempeng Eurasia (Mentawai) setiap waktunya mengalami pergerakan, sehingga terjadi gempa tektonik setiap harinya di sekitar pesisir barat Pulau Sumatera, khususnya Provinsi Bengkulu. Hal ini hendaknya dapat diamati dan dilakukan kajia-kajian yang berkelanjutan, agar dapat meminimalisir kerusakan akibat Gempa Tektonik Mentawai ini.

Kajian-kajian penelitian terkait penanggulangan bencana ini harus dilakukan, dikarenakan urgensi yang sangat bermanfaat bagi masyarakat khususnya di Provinsi Bengkulu, juga diperlukan sebagai sumber acuan rencana startegis pemerintah dalam mengatur penataan dan pengelolahan wilayar pesisir. Serta kajian ini guna mendukung dan mengembangan Rencana Induk Penelitian (RIP) Universitas Bengkulu (UNIB) tentang ekologis wilayah pesisir untuk turut aktiv dalam pembangunan wilayah, termasuk mencegah kerusakan lingkungan.

Studi pendahulu yang telah dilakukan yaitu dimulai dari; (1) Pada Tahun 2017 dilakukan penelitian tentang perancangan Sistem Pendukung Keputusan pemetaan prioritas perbaikan Jalan Jembatan, dilakukan untuk 
memberikan pendukung keputusan yang efektiv dan efisien sesuai prioritas kebutuhan [11]; (2) Pada Tahun 2019 dilakukan penelitian tentang pemetaan zonasi rawan banjir dengan analisis indeks rawan banjir menggunakan metode fuzzy simple adaptive weighting, yang menghasilkan pemetaan wilayah rawan bajir berdasarkan indeks pembobotan [12]; (3) Pada Tahun 2019 dilakukan penelitian tentang pemetaan spasial penentuan laju abrasi pantai, untuk memetakan wilayah rawan dampak laju abrasi di Kabupaten Bengkulu Tengah dan Bengkulu Utara (Setiawan et al., 2019). Dan penelitan yang menjadi rujukan berupa penelitian pemetaan kawasan rentan bencana gempa dengan mengimplementasikan metode Fuzzy Tsukamoto yang dilakukan pada Tahun 2017 [13]. Rencana selanjutnya dari usulan penelitia ini, yaitu; (I) dapat dilakukan komunikasi dan pertemuan dengan instansi Pemerintah Daerah yang terkait, sebagai bentuk pemaparan hasil peneltian yang telah dilakukan, sehingga (II) dapat menjadi sumber acuan dalam penataan dan penanggulangan bencana gempa khususnya di Provinsi Bengkulu.

Adapun tahapan-tahapan kegiatan yang dilakukan, yaitu sebagai berikut:

Tahap I. Penambangan data aktvitas Gempa Mentawai di United States Geological Survey (USGS) untuk data tahun 2009-2019.

Data aktivitas Gempa Mentawai dari tahun 2009-2019 didapatkan dengan penarikan data dengan menggunakan metode json_encode dari laman usgs.gov. Penarikan data akan menghasilkan data dalam format *.csv yang akan diubah menjadi file berformat *.xml. Data aktivitas gempa meliputi data dengan atribut; (1) waktu kejadian gempa, (2) lokasi gempa latitude-longitude, (3) kekuatan gempa, (4) teknik perhitungan kekuatan gempa, (5) error value kekuatan gempa, (6) kedalaman titik gempa, dan (7) error value kedalaman titik gempa. Metode penarikan data json_encode dilakukan sebagai representasi nilai yang dikembalikan (PHP: json_encode - Manual, n.d.).

Atribut-atribut yang didapatkan dari dataset usgs.gov diharapkan dapat menghasilkan nilai-nilai klustering yang akan dilakukan perhitungan pada tahapan berikutnya. Adapun indikator capaian yang didapatkan dari tahapan ini, yaitu; dataset Gempa Mentawai dari tahun 2009 hingga 2019 (20 tahun terakhir).

Tahap II. Analisis clustering data aktivitas gempa berdasarkan kekuatan dan kedalaman gempa dengan implementasi Algoritma K-Medoids Clustering.

Data mining merupakan proses semi otomatik yang menggunakan teknik statistik, matematika, kecerdasan buatan, dan machine learning untuk mengekstraksi dan mengidentifikasi informasi pengetahuan potensial dan berguna yang bermanfaat yang tersimpan di dalam database besar. Secara sederhana data mining adalah penambangan atau penemuan informasi baru dengan mencari pola atau aturan tertentu dari sejumlah data yang sangat besar. Data mining juga disebut sebagai serangkaian proses untuk menggali nilai tambah berupa pengetahuan yang selama ini tidak diketahui secara manual dari suatu kumpulan data.

Algoritma k-medoids adalah salah satu algoritma clustering yang terkait dengan algoritma k-means. Kmedoids dan k-means bersifat partisional (memecah dataset kedalam beberapa kelompok) dan keduanya bertujuan untuk meminimalkan jarak antara titik yang ada di dalam kluster dengan titik yang menjadi titik tengah dari kluster.

Data tribute dari dataset yang didapatkan pada tahapan sebelumnya akan dilakukan penambangan data (data mining) dengan mengimplementasikan ALgoritma KMedoids Custering. Adapun indikator capaian yang dihasilkan pada tahapan ini berupa; Hasil klustering data Gempa Mentawai (Tahun 2009-2019) berdasarkan kekuatan dan kedalaman aktivitas gempa.

Adapun gambar diagram alur kerja penelitian per indikator yang digunakan adalah sebagai berikut :



Gambar 1. Diagram Alir Penelitian Peta Pola Sebaran Gempa Metawai 2009-2019

Dapat dilihat pada Gambar 1, Flowchart Diagram diatas data yang diinputkan merupakan data kekuatan dan kedalaman gempa tahun 2009 - 2019 yang diperoleh dari website USGS.gov data kemudian diolah dengan menggunakan metode K-Medoids Clustering lalu dilakukanlah proses untuk mendapatkan clustering pola sebaran gempa nya selanjutnya hasilnya akan ditampilkan berupa peta pola sebaran gempa mentawai tahun 2010 2019.

Tahap III. Perancangan pola persebaran hasil clustering Gempa Mentawai berbasis spasial.

Sistem Informasi Geografis merupakan data yang ditempatkan dalam konteks ruang dan waktu. Nah, Sistem Informasi Geografis (SIG) atau Geographic Information Sistem (GIS) sendiri merupakan sistem berbasis komputer yang biasanya digunakan untuk menyimpan, memanipulasi, dan menganalisa informasi geografis [14]. Sebelum adanya Sistem Informasi Geografis (SIG) ini, sejumlah informasi permukaan bumi disajikan dalam peta yang dibuat secara manual. Hadirnya SIG dapat mengolah komponen peta tersebut dalam komputer, kemudian hasilnya berupa peta digital. SIG dapat menggabungkan berbagai jenis data pada satu titik tertentu yang ada di bumi, menghubungkannya, menganalisanya, hingga memetakan hasilnya. Data yang diolah oleh sistem ini adalah data spasial yakni data yang berorientasi pada 
geografis. Selain itu juga merupakan lokasi yang mempunyai koordinat tertentu.

Perancangan Sistem Informasi Geografis (SIG) pada usulan penelitian ini dirancang berbasis web, dimana data spasial akan ditampilkan dalam bentuk peta. SIG analisi dan pemetaan pola persebaran Gempa Mentawai hasil klustering dari Tahapan II. Sistem dibangun dengan tools sebagai berikut;

1. Bahasa pemrograman HTML 5 dengan penyajian content secara responsive.

2. Bahasa pemrograman PHP 5.5.

3. DBMS MySql 5.5.42.

4. Web Server Mamp Version 3.5

5. ArcGis Esri

Data-data yang telah didapatkan pada tahapan sebelumnya akan dimasukkan dan diolah dengan menggunakan SIG yang telah dibangun pada tahapan ini, sehingga pada tahapan ini menghasilkan data keluaran berupa hasil pemetaan pola persebaran Gempa Mentawai hasi klustering dengan mengimplementasikan ALgoritam KMedoids Clustering.

\section{Tahap IV. Pengujian Sistem}

Pada penelitian ini digunakan metode pengujian kotak hitam (Black-Box Testing) yaitu menguji perangkat lunak dari segi spesifikasi fungsional tanpa menguji desain dan kode program. Pengujian dimaksudkan untuk mengetahui apakah fungsi-fungsi, masukan, dan keluaran dari perangkat lunak sesuai dengan spesifikasi yang dibutuhkan. Pengujian kotak hitam dilakukan dengan membuat kasus uji yang bersifat mencoba semua fungsi dengan memakai perangkat lunak apakah sesuai dengan spesifikasi yang dibutuhkan. Kasus uji yang dibuat untk melakukan pengujian kotak hitam harus dibuat dengan kasus benar dan kasus salah. Confusion matrix adalah suatu metode yang biasanya digunakan untuk melakukan perhitungan akurasi pada konsep data mining

\section{Hasil Dan Pembahasan}

Perancangan Sistem Informasi Geografis (SIG) pada usulan penelitian ini dirancang berbasis web, dimana data spasial akan ditampilkan dalam bentuk peta. SIG analisi dan pemetaan pola persebaran Gempa Mentawai hasil klustering. Pada bagian sub menu implementasi sistem ini akan membahas penerapan perancangan kedalam sistem informasi pola sebaran gempa ini. Pada sistem ini, terdapat halaman yang dapat diakses langsung oleh pengguna secara umum dan dapat juga diakses oleh aktor admin untuk melakukan manajemen data. Untuk dapat melakukan manajemen sistem admin diharuskan untuk masuk kedalam sistem terlebih dahulu dengan menginputkan username dan password yang benar.

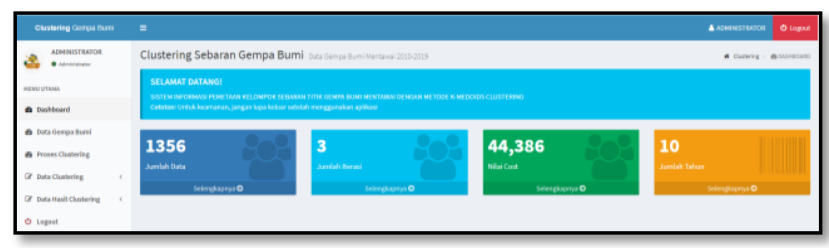

Gambar 2. Halaman Dashboard

Halaman Dashboard diatas merupakan tampilan sistem awal yang memuat informasi tentang jumlah data sebanyak 1356 data, jumlah iterasi, jumlah nilai cost dan jumlah tahun sebanyak 10 tahun yaitu tahun 2010, 2010, 2011, 2012, 2013, 2014, 2015, 2016, 2017, 2018 san 2019. Pada halaman data gempa bumi mentawai diatas merupakan halaman yang berisi informasi data gempa bumi mentawai berupa koordinat daerah yang terbagi berdasarkan latitude dan longitude, kedalaman dan kekuatan gempa dan yang terakhir terdapat informasi nama lokasi terjadinya gempa tersebut.

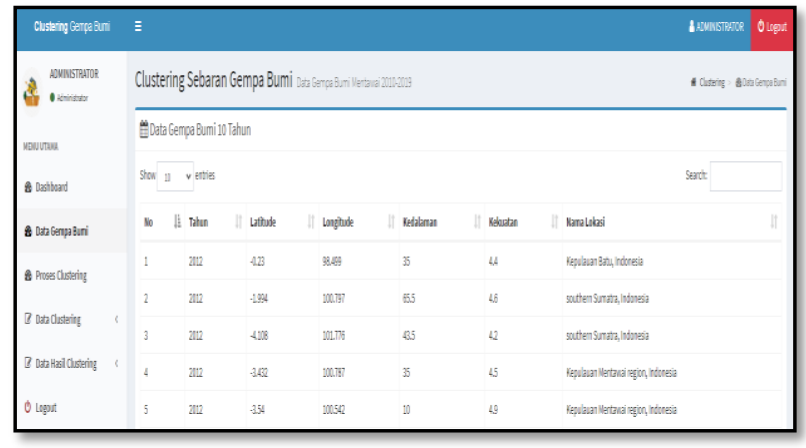

Gambar 3. Halaman Data Gempa Bumi Mentawai

Pada halaman Proses Clustering tersebut merupakan halaman yang berisi tentang jumlah iterasi yang dilakukan, jumlah iterasi ini akan berhenti jika nilai cost saat ini lebih besar dari jumlah cost sebelumnya, pada gambar memberikan informasi terdapat 3 iterasi, selait itu terdapat juga hasil dari jumlah clustering 1 , clustering 2 dan clustering 3 karena penelitian ini membagi menjadi 3 clustering. Selain itu, juga akan memberikan informasi mengenai data latitude, longitude, kedalaman, kekuatan dan tahun terjadi gempa.

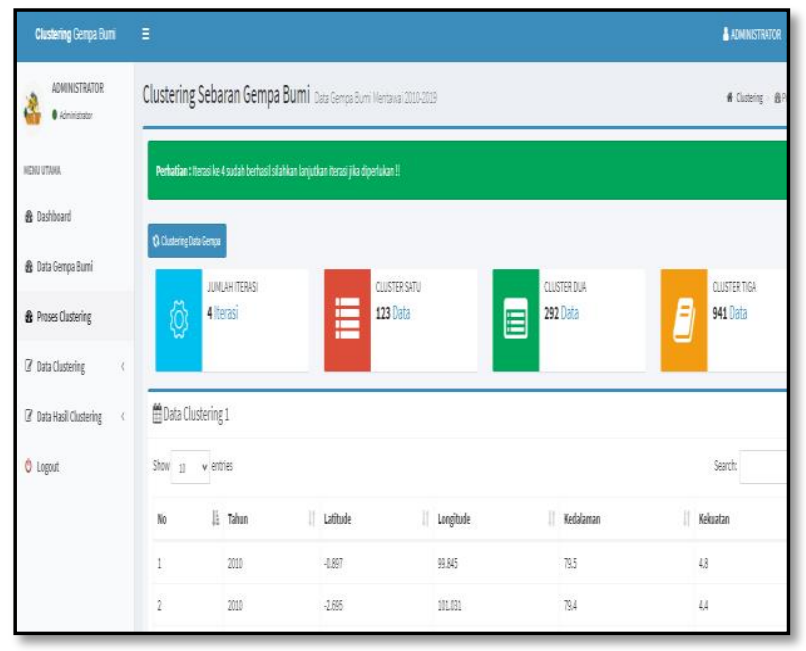

Gambar 4. Halaman Proses Clustering 
Pada halaman Data Clustering (Pusat Cluster) diatas memberikan informasi data-data pusat cluster yang dipilih secara random data yang ditampilkan berupa data iterasi ke, cluster ke, dan data kedalaman serta kekuatannya.

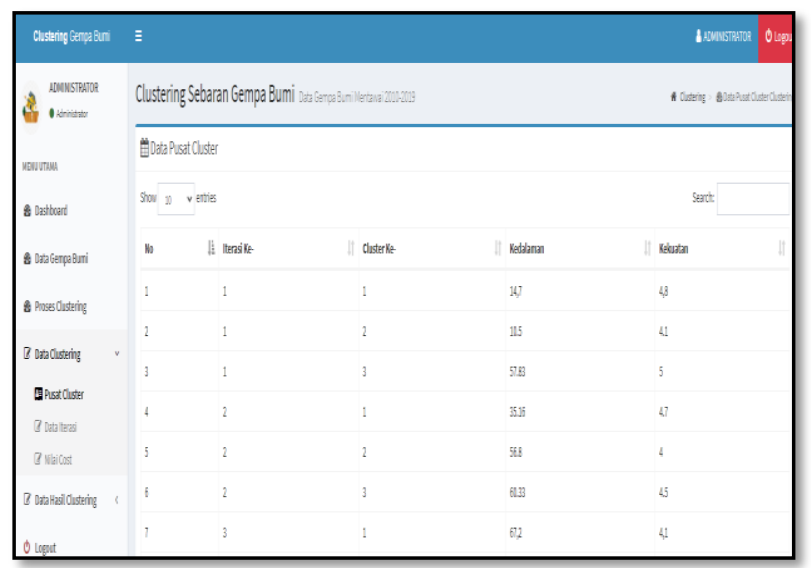

Gambar 5. Data Clustering (Pusat Cluster)

Pada halaman Data Clustering (Data Iterasi) diatas memberikan informasi dari data kedalaman, kekuatan, nilai cluster 1 , nilai cluster 2 , nilai cluster 3 , nilai minimal dari nilai cluster 1 , cluster 2 dan cluster 3 . Mengambil nilai minimal karena mencari jarak terkecil antara objek dan pusat cluster. Selanjutnya terdapat informasi kelompok cluster. Kelompok cluster disini maksudnya data tersebut termasuk kedalam cluster berapa, jika nilai minimal terdapat pada cluster 3 misalnya, maka data tersebut termasuk dalam kelompok cluster 3. Serta yang terakhir memberikan informasi mengenai iterasi keberapa.

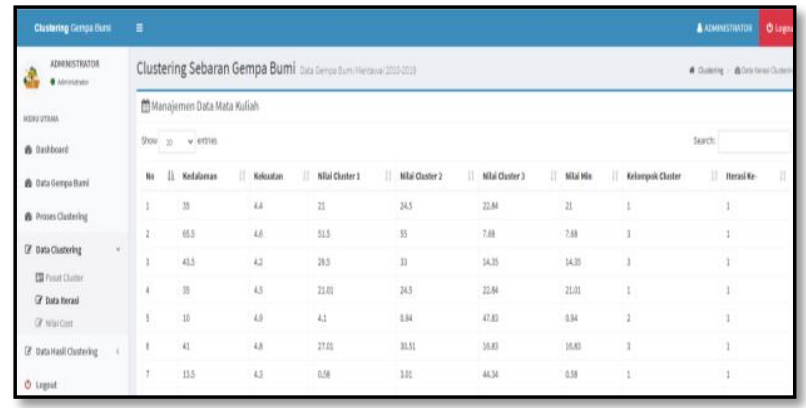

Gambar 6. Halaman Data Clustering (Data Iterasi)

Pada halaman tampilan data dalam bentuk grafik diatas memberikan informasi mengenai jumlah data setiap cluster yang terdapat pada cluster 1 , cluster 2 dan cluster 3. Data tersebut disajikan kedalam bentuk grafik batang dan grafik lingkaran.

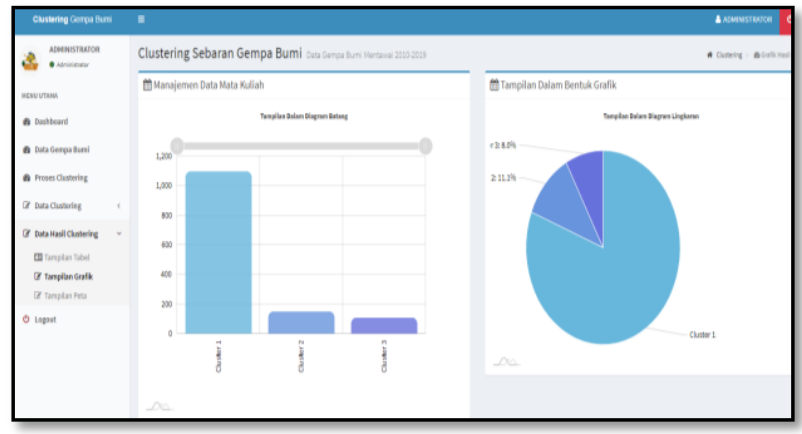

Gambar 7. Halaman Tampilan Data Dalam Bentuk Grafik

Pada tampilan data dalam bentuk peta diatas memberikan informasi pola sebaran yang dihasilkan dari 3 cluster, dengan masing-masing warna garis biru, merah dan kuning. Setiap titik koordinat akan dihubungkan dengan garis.

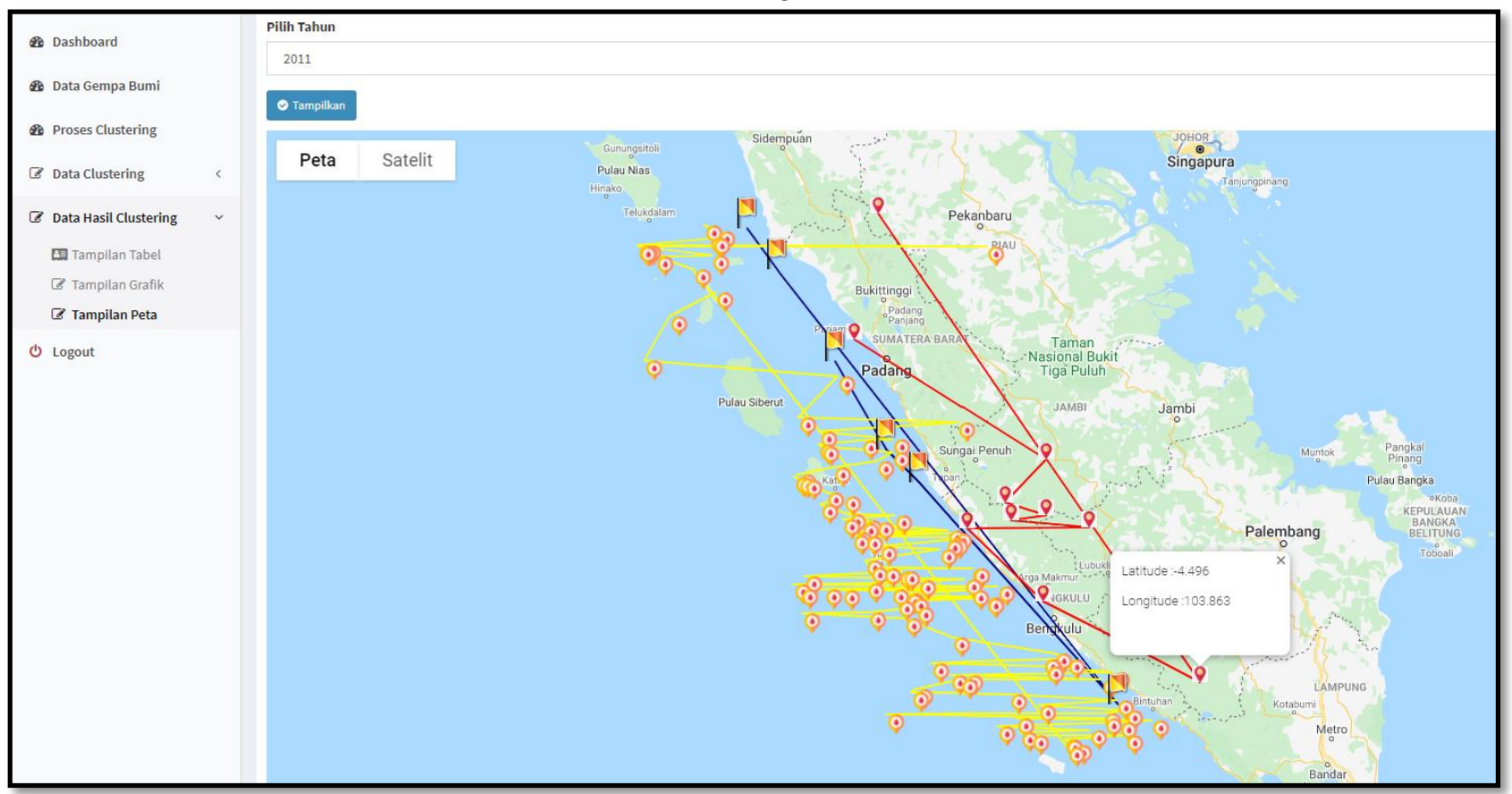

Gambar 8. Hasil Pemetaan Pola Sebaran Gempa Mentawai 
Pada penelitian ini, akan dilakukan perhitungan dengan menggunakan metode $\mathrm{K}$-Medoids Clustering, maka akan dilakukan perhitungan dengan mencari pusat cluster sebanyak $k$ yaitu samadengan 3. Sebelum ketahapan perhitungan, berikut merupakan data yang akan diolah nantinya :

Tabel 1. Data Penelitian

\begin{tabular}{lllll}
\hline Tahun & latitude & Longitude & depth & Mag \\
\hline 2019 & -2.0879 & 100.618 & 64.65 & 4.5 \\
2019 & -4.2173 & 102.1178 & 73.43 & 4.2 \\
2019 & -2.2276 & 99.3207 & 10 & 4.4 \\
2019 & -2.8469 & 100.9598 & 35 & 4.4 \\
2019 & -2.9702 & 100.9448 & 40.28 & 5.6 \\
2019 & 0.5676 & 99.8691 & 167.24 & 4.7 \\
2019 & -4.5951 & 102.2283 & 42.56 & 4.7 \\
2019 & -0.9072 & 97.9212 & 10 & 5 \\
2019 & -0.9122 & 97.8908 & 10 & 4.7 \\
2019 & -5.2035 & 103.6705 & 69.84 & 4.8 \\
\hline
\end{tabular}

a. Inisialisasi Pusat Cluster sebanyak k

Pada penelitian ini digunakan 3 cluster yaitu gempa rendah, gempa sedang dan gempa tinggi. Jadi $\mathrm{k}=3$. Berikut merupakan tabel pusat cluster.

Tabel 2. Pusat Cluster

\begin{tabular}{ccc}
\hline Cluster & Kedalaman & Kekuatan \\
\hline 1 & 69.02 & 4.6 \\
2 & 46.15 & 4.1 \\
3 & 59.2 & 5 \\
\hline
\end{tabular}

b. Alokasikan setiap data (objek) ke cluster terdekat menggunakan persamaan ukuran jarak Euclidian Distance sebagai berikut :

$1,2,3, \ldots, \mathrm{n}$

$$
\mathrm{d}(\mathrm{x}, \mathrm{y})=\|\mathrm{x}-\mathrm{y}\|=x=\sqrt{\sum_{i=1}^{n}\left(x_{i}-y_{i}\right)^{2}}
$$

Untuk mendapatkan jarak Euclidian distance lakukan perhitungan dengan persamaan 2.1 seperti diatas antara tabel 1 data penelitian pada kolom depth dan mag dengan tabel 2. pusat cluster kolom kedalaman dan kekuatan. Perhatikan perhitungan dibawah berikut :

\section{c. Proses Jarak Minimal}

Untuk mencari jarak minimum sebaiknya buatlah tabel perbandingan nilai antara cluster 1, 2, dan 3. Selanjutnya pilih nilai paling kecil dari 3 cluster tersebut. Perhatikan nilai minimum yang diambil, jika nilai minimum berasal dari distance pertama artinya data tersebut termasuk kedalam cluster ke-1 begitu seterusnya. Perhatikan tabel berikut :

Tabel 3. Jarak Minimal

\begin{tabular}{ccccc}
\hline Distance & Distance & Distance & \multirow{2}{*}{ Nilai } & Clus \\
69.02 & 46.15 & 59.2 dan & Minimum & ter \\
dan 4.6 & dan 4.1 & 5 & & ke- \\
\hline
\end{tabular}

\begin{tabular}{ccccc}
\hline 4.371144 & 18.50432 & 5.472887 & 4.371144 & 1 \\
015 & 382 & 72 & 015 & \\
4.428103 & 27.28018 & 14.25246 & 4.428103 & 1 \\
431 & 328 & 996 & 1431 & \\
59.02033 & 36.15124 & 49.56 & 36.15124 & 2 \\
887 & 479 & & 479 & \\
34.02058 & 11.15403 & 24.56 & 11.15403 & 2 \\
788 & 514 & & 514 & \\
28.75739 & 6.058621 & 19.28 & 6.058621 & 2 \\
209 & 956 & & 956 & \\
98.22005 & 121.0914 & 108.13 & 98.22005 & 1 \\
091 & 865 & & 091 & \\
26.46018 & 3.639793 & 16.73 & 3.639793 & 2 \\
896 & 95 & & 95 & \\
59.02135 & 36.16120 & 49.2 & 36.16120 & 2 \\
546 & 158 & & 158 & \\
59.02008 & 36.15497 & 49.20091 & 36.15497 & 2 \\
472 & 891 & 463 & 891 & \\
0.844037 & 36.15497 & 10.68 & 0.844037 & 1 \\
914 & 891 & & 914 & \\
\hline & & & &
\end{tabular}

\section{d. Hitunglah Total Simpangan}

Untuk menghitung jumlah total simpangan adalah dengan menjumlahkan semua data yang termasuk kedalam kolom nilai.

Nilai cost $=4.371144015+4.4281031431+36.15124479$

$+11.15403514+6.058621956+98.22005091+$ $3.63979395+36.16120158+36.15497891+$ $\mathbf{0 . 8 4 4 0 3 7 9 1 4}=\mathbf{2 3 7 . 1 8 3 2 1 2 3}$.

Setelah didapatkan total simpangan (cost) maka clustering sudah terbentuk seperti pada tabel 5.4. jarak minimal. Akan tetapi lakukan iterasi selanjutnya dengan melakukan perhitungan seperti pada poin b sampai poin $d$ untuk mendapatkan nilai cost yang baru. Selanjutnya setelah nilai cost baru didapatkan lakukanlah pengurangan antara total simpangan (cost) lama dengan total simpangan (cost) baru. Jika $\mathrm{S}<0$, maka tukar objek dengan data cluster untuk membentuk sekumpulan $k$ objek baru sebagai medoid.

e. Ulangi langkah a sampai d untuk mendapatkan nilai total simpangan baru.

f. Hitung total simpangan (S) dengan menghitung nilai total distance baru - total distance lama. Jika $\mathrm{S}<0$, maka tukar objek dengan data cluster untuk membentuk sekumpulan $k$ objek baru sebagai medoid.

g. Ulangi semua langkah diatas hingga tidak terjadi perubahan medoid, sehingga didapatkan cluster beserta anggota cluster masing-masing

\subsection{Hasil Pengujian Matriks Confusion}

Confusion matrix adalah suatu metode yang biasanya digunakan untuk melakukan perhitungan akurasi pada konsep data mining. [10].

Tabel 4. Jumlah Data Gempa Pada masing-masing cluster

\begin{tabular}{lcc}
\multicolumn{2}{c}{ Cluster } & \\
(sedang) & Cluster 2 & Cluster 3 \\
(rendah) & (Tinggi)
\end{tabular}




\begin{tabular}{lllc}
\hline Rendah & 0 & 6 & 0 \\
Sedang & 3 & 0 & 0 \\
Tinggi & 3 & 5 & 111 \\
\hline
\end{tabular}

Berdasarkan pada tabel 4. Jumlah Data Gempa Pada Masing-Masing Cluster diatas cluster 1 mewakili rendah yaitu gempa dangkal, cluster 2 mewakili sedang yaitu gempa sedang, dan cluster 3 mewakili gempa dalam. Selanjutnya akan dilakukan penentuan jumlah data true positive, true negative, false positive, dan false negative untuk setiap gempa yang dapat dilihat pada perhitungan berikut :

Tabel 5. Data Arsir Abu-abu Merupakan True Positive

\begin{tabular}{lllll}
\hline & $\begin{array}{l}\text { Cluster } \\
\text { (sedang) }\end{array}$ & $\begin{array}{l}\text { Cluster } \\
\text { (rendah) }\end{array}$ & $\begin{array}{l}\text { Cluster } \\
\text { (Tinggi) }\end{array}$ & 3 \\
\hline Rendah & 0 & 6 & 0 \\
Sedang & 3 & 0 & 0 \\
Tinggi & 3 & 5 & 111 \\
\hline
\end{tabular}

Nilai yang terdapat dalam arsir abu-abu merupakan nilai true positive dari renda, sedang dan tinggi.

Tabel 6. Data arsir merah (sedang), kuning (rendah), hijau tua (tinggi) merupakan True Negative

\begin{tabular}{llllll} 
& $\begin{array}{l}\text { Cluster } \\
\text { (sedang) }\end{array}$ & $\begin{array}{l}\text { Cluster } \\
\text { (rendah) }\end{array}$ & $\begin{array}{l}\text { Cluster } \\
\text { (Tinggi) }\end{array}$ & 3 \\
\hline Rendah & 0 & 6 & 0 & \\
Sedang & 3 & 0 & 0 & \\
Tinggi & 3 & 5 & 111 & \\
\hline
\end{tabular}

Untuk mengetahui nilai true negative dari gempa rendah jumlahkan angka yang diarsir merah arsir kuning untuk true negatif gempa sedang dan arsir hijau tua untuk mendapatkan nilai true negative gempa tinggi.

Tabel 7. Data arsir biru (rendah), jingga (sedang), coklat (tinggi) merupakan False Positive

\begin{tabular}{llllll}
\hline & $\begin{array}{l}\text { Cluster } \\
\text { (sedang) }\end{array}$ & $\begin{array}{l}\text { Cluster } \\
\text { (rendah) }\end{array}$ & $\begin{array}{l}\text { Cluster } \\
\text { (Tinggi) }\end{array}$ & 3 \\
\hline Rendah & 0 & 6 & 0 & \\
Sedang & 3 & 0 & 0 & \\
Tinggi & 3 & 5 & 111 & \\
\hline
\end{tabular}

Jumlahkan angka pada kolom biru untuk mendapatkan nilai false positive cluster rendah, kolom berwarna jingga untuk mendapatkan false positive cluster sedang dan kolom cokelat untuk mendapatkan nilai false positive cluster tinggi.

Tabel 8. Data merah muda (rendah), hijau muda (sedang), ungu (tinggi) merupakan False Negative

\begin{tabular}{lllll}
\hline & $\begin{array}{l}\text { Cluster } \\
\text { (sedang) }\end{array}$ & $\begin{array}{l}\text { Cluster } \\
\text { (rendah) }\end{array}$ & $\begin{array}{l}\text { Cluster } \\
\text { (Tinggi) }\end{array}$ & 3 \\
\hline Rendah & 0 & 6 & 0 \\
Sedang & 3 & 0 & 0 \\
Tinggi & 3 & 5 & 111 \\
\hline
\end{tabular}

Jumlahkan angka pada kolom berwarna merah muda untuk mendapatkan nilai false negative cluster rendah, kolom berwarna hijau muda untuk mendapatkan false negative cluster sedang, dan kolom berwarna ungu untuk mendapatkan nilai false negative cluster tinggi.
Tabel 9. Hasil Akhir TP, TN, FP, FN

\begin{tabular}{lllll}
\hline & True & True & False & False \\
& Positive & Negative & Positive & Negative \\
\hline Rendah & 6 & 117 & 3 & 0 \\
Sedang & 3 & 116 & 5 & 0 \\
Tinggi & 111 & 9 & 0 & 8 \\
\hline
\end{tabular}

True positive adalah data yang memiliki hasil prediksi positif dan nilai sebenarnya positif. True negative adalah data yang memiliki hasil prediksi salah dan nilai sebenarnya juga salah. False positive adalah data yang memiliki hasil prediksi benar sedangkan nilai yang sebenarnya salah. False negative adalah data yang memiliki hasil prediksi salah sedangkan nilai yang sebenarnya benar [10].

Setelah itu, dilakukan perhitungan akurasi per cluster dengan menggunakan data pada Tabel-tabel diatas dengan menggunakan rumus Akurasi pada Confusion Matrix .

$$
\begin{aligned}
& \text { Cluster } \mathrm{A}=\frac{T P \text { data } A+T N \text { data } A}{n} \times 100 \% \\
& \text { Cluster } \text { Rendah }=\frac{6+117}{128} \times 100 \%=96.09 \% \\
& \text { Cluster } \text { Sedang }=\frac{3+116}{128} \times 100 \%=92.96 \% \\
& \text { Cluster } \text { Tinggi }=\frac{111+9}{128} \times 100 \%=93.75 \% \\
& \text { Akurasi sistem }=\frac{96.09 \%+92.96 \%+93.75 \%}{3}=94.267 \\
& \%
\end{aligned}
$$

Berdasarkan perhitungan di atas, persentase akurasi sistem dalam mengenal cluster rendah adalah $96.09 \%$, cluster sedang 92.96\% dan cluster tinggi $93.75 \%$. Cluster rendah memiliki tingkat presentasi akurasi paling rendah karena banyak data cluster lain yang dikelompokkan pada cluster ini (false positive). Persentase akurasi keseluruhan sistem dalam mengelompokkan ketiga cluster (rendah, sedang, tinggi) adalah $94.267 \%$.

\section{Kesimpulan}

Berdasarkan hasil penelitian dan pembahasan yang telah dilakukan maka Terbentuknya peta pola sebaran titik gempa bumi Mentawai tahun 2009 - 2019 sebanyak tiga (3) cluster yaitu cluster 1 rendah yang merupakan gempa dalam, cluster 2 gempa sedang dan cluster 3 tinggi yaitu gempa dangkal. Terdapat persebaran data sebanyak $14 \%$ untuk data Gempa Mentawai Cluster 3, dimana persebaran titik gempa berada menedekati garis pantai (dangkal) dan dengan kekuatan gempa yang tinggi. Terdapat sebaran data sebesar $12 \%$ data Gempa Menatawai Cluster 2, dimana persebaran titik gempa berada di daratan. Terdapat sebaran data sebesar $74 \%$ data Gempa Mentawai Cluster 1, dimana gempa berada jauh dari garis pantai. Terbentuknya grafik dengan diagram batang dan diagram lingkaran hasil analisis terhadap pola sebaran titik gempa Mentawai tahun $2009 \quad-\quad 2019$ dengan mengimplementasikan metode K-Medoids Clustering.

\section{Ucapan Terimakasih}

Kami mengucapkan banyak terima kasih kepada Menteri Pendidikan dan Kebudayaan, Lembaga Penelitian dan 
Pengabdian Kepada Masayarakat (LPPM) Universitas Bengkulu, dan Fakultas Teknik atas dukungan finansial dan panduan sehingga penelitian ini terlaksana dengan baik.

\section{Daftar Pustaka}

[1] A. M. Nur, "Gempa Bumi, Tsunami Dan Mitigasinya," Jurnal Geografi, Vol. 7, Pp. 66-73, 2010.

[2] L. Septiningrum Dan M. N. Cahyadi, "Analisis Perubahan Lonosfer Akibat Gempa," Journal Teknik Vol 5, No.2, (2016) ISSN, Vol. C176, 2016.

[3] B. N. P. B. BNPB, "Rencana Aksi Rehabilitasi Dan Rekonstruksi Pasca Bencana, Serta Percepatan Pembangunan Wilayah Kepulauan Mentawai Provinsi Sumatera Barat," Sumatera Barat, 2010

[4] J. Han, M. Kamber Dan J. Pei, "Data Mining Concepts And Techniques," Dalam Third Edition, D. Cerra, Penyunt., San Francisco, Elsevier, 2012, Pp. 454-457.

[5] R. R. Arista, R. A. Asmara Dan . D. Puspitasari, "Pengelompokkan Kejadian Gempa Bumi Menggunakan Fuzzy C-Means Clustering," Jurnal Teknologi Informatika Dan Terapan, Vol. 4, Pp. 103-110, 2017.

[6] A. S. D. Simamora, M. T. Furqon Dan B. Priyambadha, "Clustering Data Kejadian Tsunami Yang Disebabkan Oleh Gempa Bumi Dengan Menggunakan Algoritma K-Medoids," Jurnal Pengembangan Teknologi Informasi Dan Ilmu Komputer, Vol. 1, Pp. 635-640, 2017.

[7] P. B. R. Sitorus, "Budaya Kerentanan Dan Kapasitas Masyarakat Kepulauan Mentawai Menghadapi Bencana Gempa Bumi Dan Tsunami,” Jurnal Vokasi Indonesia, Vol. 6, Pp. 25-32, 2018.

[8] R. Fidia, . D. Pujiastuti Dan A. Z.Sabarani, "Korelasi Tingkat Seismisitas Dan Periode Ulang Gempa
Bumi Di Kepulauan Mentawai Dengan Menggunakan Metode Guttenberg Richter,' Jurnal Fisika Unand, Vol. 7, Pp. 84-89, 2018.

[9] H. Nawawi Dan M. Martini, Penelitian Terapan, Yogyakarta: Gadjah Mada Univercity Press, 2005.

[10] M. F. Rahman, M. L. Darmawidjadja Dan D. Alamsah, "Klasifikasi Untuk Diagnosa Diabetes Menggunakan Metode Bayesian Regularization Neural Network (Rbnn)," Jurnal Informatika, Vol. 11, Pp. 36-45, 2017.

[11] Oktariani, D., Andreswari, D., \& Setiawan, Y. (2017). Sistem Pendukung Keputusan Dalam Pemetaan Prioritas Perbaikan Jalan Dan Jembatan Nasional Di Provinsi Bengkulu Menggunakanmetode Topsis Dan Fuzzy C-Means. Jurnal Rekursif, 05(02), 166-179

[12] Setiawan, Y., Efendi, R., Susilo, B., Andreswari, D., \& Adha, Q. Y. E. (2019). Spatial and Non-Spatial Analysis Using Bayes Theorem Method to Determine Coastal Abrasion Rate Classification (On The Coast of Central Bengkulu and North Bengkulu Regency, Indonesia). Proceeding ICETSAS 2019.

[13] Anggarini, L. R., Ernawati, \& Purwandari, E. P. (2017). Pemetaan Kawasan Kecamatan Rentan Bencana Gempa Di Kota Bengkulu Menggunakan Fuzzy Tsukamoto. Jurnal Rekursif, 5(3), 260-269.

[14] Prameswari, S. (2018, March 31). Sistem Informasi Geografis : Jenis - Manfaat - Tujuan - Sumber Data. IlmuGeografi.com. https://ilmugeografi.com/geografi-teknik/sisteminformasi-geografis 